\title{
Impaired Lymphocyte Function in Aged Humans
}

\author{
Marc E. Weksler and Thomas H. Hütteroth \\ From the Division of Allergy and Immunology and Division of Human \\ Genetics, Department of Medicine, New York Hospital-Cornell Medical Center, \\ New York 10021
}

A B S T R A C T The response of lymphocytes from young
and old persons to phytohemagglutinin, pokeweed mito-
gen, or allogeneic lymphocytes has been measured.
Lymphocytes from old persons incorporated significantly
less tritiated thymidine as compared with lymphocytes
from young persons when cultured with plant mitogens
or allogeneic cells. The difference in observed lympho-
cyte reactivity could not be attributed to differences in
culture conditions required for maximal transformation
of lymphocytes from old or young subjects. The same
percentage of thymus-derived and bone marrow-derived
lymphocytes was found in the blood from old and young
persons. The relationship of these findings to the de-
cline of immunologic competence with age is discussed.

\section{INTRODUCTION}

The concept of immune surveillance suggests that the growth of neoplasms may reflect a failure of cell-mediated immunity. As the occurrence of cancer increases with age from an incidence of $13 / 100,000$ persons at age $15 \mathrm{yr}$ to $3,000 / 100,000$ persons at age 90 (1), this hypothesis implies that cellular immune responses should decline with age. We have tested this prediction by comparing several parameters of immunological competence in persons less than $40 \mathrm{yr}$ old and in persons over $75 \mathrm{yr}$ old. The lymphocyte response to plant mitogens and allogeneic cells has been measured. Our results show that the response of lymphocytes from old persons to allogeneic lymphocytes and to plant mitogens is depressed compared with the response of lymphocytes from young persons.

\section{METHODS}

Subjects. Blood was obtained from 25 persons between the ages of 25 and $40 \mathrm{yr}$ and from 23 persons between the ages of 75 and 96 . Care was taken to select subjects free from diseases known to effect the reactivity of lym-

Received for publication 22 June 1973 and in revised form 27 August 1973. phocytes in culture. Most of the older subjects had arteriosclerotic cardiovascular disease. None of the subjects tested were taking drugs aside from vitamins, ferrous sulfate, or laxatives. All subjects tested were Caucasian.

Lymphocyte culture. $12 \mathrm{ml}$ of blood was drawn into a syringe containing $100 \mathrm{U}$ of heparin (The Upjohn Co., Kalamazoo, Mich.) and mixed in the syringe with an equal volume of sterile $0.15 \mathrm{M} \mathrm{NaCl} .12 \mathrm{ml}$ of diluted blood was layered over $3 \mathrm{ml}$ of a mixture of Ficoll and sodium diatrizoate (Hypaque) in a $17 \times 100 \mathrm{~mm}$ plastic tube (Falcon 2030, Falcon Plastics, Los Angeles, Calif.) a technique modified after Boyum (2). The Ficoll-Hypaque mixture consisted of one part $8 \%$ (wt/vol) Ficoll (Pharmacia Fine Chemicals, Inc., Piscataway, N. J.) mixed with four parts of $50 \%$ Hypaque (Winthrop Laboratories, New York). The density of the mixture was adjusted to 1.0781.080 with distilled water. The preparation was sterilized by passage through a $0.45 \mu \mathrm{m}$ Millipore filter (Millipore Corp., Bedford, Mass.). The tubes containing the FicollHypaque overlaid with blood were centrifuged at $800 \mathrm{~g}$ for $20 \mathrm{~min}$ at room temperature. The layer of mononuclear cells at the plasma Ficoll-Hypaque interface was removed. suspended in medium RPMI 1,640 with $100 \mathrm{U} / \mathrm{ml}$ penicillin, $50 \mu \mathrm{g} / \mathrm{ml}$ streptomycin, and fresh glutamine $2 \mathrm{mM}$ (Associated Biomedic Systems, Inc., Buffalo, N. Y.), and centrifuged for $10 \mathrm{~min}$ at $180 \mathrm{~g}$. The supernate was discarded and the cells resuspended at a concentration of $2 \times 10^{\mathrm{A}}$ lymphocytes/ml in culture medium with $10 \%$ heat-inactivated human $A B$ serum screened for atypical antibodies. Lymphocytes represented $90 \%$ of the white cells recovered. $22-69 \%$ of the blood lymphocytes were recovered. Lymphocyte recovery from blood of old or young subjects was the same. Iron-dextran separation increased the purity of lymphocytes recovered $(95 \%)$ without significantly altering the yield. Lymphocyte cultures were established in triplicate in sterile multiwell plates (Linbro IS FB 96 TC, Linbro Chemical Co., New Haven, Conn.) in a total volume of $0.2 \mathrm{ml}$. $\frac{1}{10} \mathrm{ml}$ of purified lymphocytes containing $2 \times 10^{5}$ lymphocytes was mixed with $1 \mu \mathrm{g}$ of purified phytohemagglutinin (PHA) ${ }^{1}$ (Burroughs Wellcome Co., Research Triangle Park, N. C.) in $0.1 \mathrm{ml}$ of culture medium, or with $2 \mu 1$ of reconstituted pokeweed mitogen (PWM) (Grand Island Biological Co., Grand Island, N. Y.) diluted to $0.1 \mathrm{ml}$ with culture medium or with $0.1 \mathrm{ml}$ of medium containing $2 \times 10^{5}$ allogeneic lymphocytes irradiated with 3,000 rads. Control cultures consisted of lymphocytes

${ }^{1}$ Abbreviations used in this paper: $\mathrm{PHA}$, phytohemagglutinin; PWM, pokeweed mitogen. 
cultured with medium containing no mitogen or with irradiated autologous lymphocytes. Lymphocyte cultures containing mitogen were incubated for $72 \mathrm{~h}$, mixed lymphocyte cultures were incubated for $120 \mathrm{~h}$. All cultures were incubated at $37^{\circ} \mathrm{C}$ in a $5 \% \quad \mathrm{CO}_{2} / 95 \%$ air environment. $6 \mathrm{~h}$ before the termination of the culture period, $1 \mu \mathrm{Ci}$ [methyl ${ }^{8} \mathrm{H}$ ] thymidine in a $1 \mu l$ volume (sp act $2 \mathrm{Ci} / \mathrm{mM}$, New England Nuclear, Boston, Mass.) was added to each well. At the end of the incubation period lymphocytes were aspirated from the individual wells and washed with distilled water using an apparatus based on a design of Hartzman, Segall, Bach, and Bach (3). The labeled material was collected on glass fiber paper $(H$. Reeve Angel \& Co., Inc., Clifton, N. J.), placed into $14.5 \times 45-\mathrm{mm}$ vials to which $2.5 \mathrm{ml}$ of Aquasol (New England Nuclear) was added. The small vials were placed inside standard scintillation vials and counted in a liquid scintillation counter. The counting efficiency for tritium in these conditions was $34 \%$. The results of mitogen stimulation are given as the increment in thymidine incorporated in the presence of mitogen. The results of one-way mixed lymphocyte reaction are expressed by the stimulation index. The incorporation of $\left[{ }^{3} \mathrm{H}\right]$ thymidine in one-way mixed lymphocyte culture was divided by one-half the sum of the $\left[{ }^{8} \mathrm{H}\right]$ thymidine incorporated by each member of the culture mixed with irradiated autologous lymphocytes.

Identification of membrane immunoglobulin-bearing and sheep red cell rosette-forming lymphocytes. To isolate lymphocytes, $20 \mathrm{ml}$ of blood was drawn into a syringe containing 1,000 U Heparin, $60 \mathrm{mg}$ carbonyl iron (General Aniline \& Film Corp., Easton, Pa.) in $5 \mathrm{ml} 6 \%$ dextran (Abbott Laboratories, North Chicago, Ill.). After incubation in the syringe for $30 \mathrm{~min}$ at $37^{\circ} \mathrm{C}$, the mixture was layered on top of Ficoll-Hypaque mixture. The cells isolated as described above were resuspended in $1 \mathrm{ml}$ Hank's solution, counted, and adjusted to a concentration of $1 \times 10^{7}$ lymphocytes $/ \mathrm{ml}$ (90-95\% of the cells were small mononuclear lymphocytes).

Preparation of antisera. Antisera to purified human monoclonal proteins were raised in rabbits and absorbed with insoluble immunoadsorbents as described previously (4). Two of such antisera were pooled to yield an antiserum with specificity for kappa and lambda light and mu and gamma heavy chains. Conjugation of these anti- bodies with fluorescein isothiocyanate was performed after purification of the gamma globulin fraction (5). The labeled antibody had a fluorescein protein ratio of 2.9 and was used at a protein concentration of $2-3 \mathrm{mg} / \mathrm{ml}$.

Preparation of sheep red cells. Sheep red cells were obtained from Animal Blood Centre, Inc., Syracuse, N. Y. The cells were treated with neuraminidase from Vibrio Cholerae (Behring Diagnostics, Woodbury, N. Y.) to enhance their binding to lymphocytes, as described by Weiner, Bianco, and Nussenzweig (6).

Combined assay for membrane immunoglobulin-bearing and sheep red cell rosette-forming cells. $0.05 \mathrm{ml}$ of purified lymphocytes containing $0.5 \times 10^{6}$ cells was mixed with $0.05 \mathrm{ml}$ of appropriately diluted fluorescein-conjugated antiserum and incubated for $15 \mathrm{~min}$ at room temperature. After two washings, cells were resuspended in $0.5 \mathrm{ml}$ Hank's solution and $0.5 \mathrm{ml}$ of a $0.5 \%$ neuraminidase-treated sheep red cell suspension was added. The cell mixture was incubated for $15 \mathrm{~min}$ at $37^{\circ} \mathrm{C}$ in a water bath, centrifuged for $10 \mathrm{~min}$ at $200 \mathrm{~g}$ at room temperature, and incubated for $15 \mathrm{~min}$ on ice. Two-thirds to three-quarters of the supernate was removed and the cell button gently resuspended. The preparation was examined as suspension under a nail polish-sealed cover glass with a Zeiss Universal Microscope (Carl Zeiss, Inc., New York) under phase contrast illumination and with incident light immunofluorescence employing HBO 200 mercury lamp, BG 38 and BG 12 excitation filters, and 52 barrier filter. Each field was evaluated for immunofluorescent cells, rosetted cells, and "null cells," for each preparation at least 200 cells were examined.

Statistical analysis. Experimental groups were compared statistically using the unpaired Student's $t$ test. The mean and standard error of the mean are given.

\section{RESULTS}

Response of lymphocytes from old and young subjects to plant lectins. Lymphocytes from old and young subjects were cultured in the absence and the presence of PHA or PWM. Lymphocytes from old subjects incorporate less thymidine into DNA in the absence and in

TABLE I

Response to Lymphocytes from Old and Young Persons to PHA orPWM*

\begin{tabular}{lccc}
\hline & Mitogen & \multicolumn{2}{c}{ Mitogen present } \\
\cline { 3 - 4 } Lymphocyte donors & cpsent & PHA & PWM \\
\hline \multirow{2}{*}{ Young persons (25) } & $487 \pm 61 \ddagger$ & \multicolumn{2}{c}{ cpm/cullure } \\
& $(100-900) \|$ & $(2,900-98,611) \|$ & $(400-60,300) \|$ \\
Old persons. $(23)$ & $369 \pm 62 \ddagger$ & $20,952 \pm 3,356 \S$ & $5,440 \pm 887 \S$ \\
& $(100-700) \|$ & $(3,010-63,140) \|$ & $(900-19,200) \|$
\end{tabular}

* $2 \times 10^{5}$ lymphocytes were cultured with and without PHA or PWM for 3 days in $0.2 \mathrm{ml}$ volume of medium RPMI 1,640 with $10 \% \mathrm{AB}$ serum. $6 \mathrm{~h}$ before the termination of culture $1 \mu \mathrm{Ci}$ of $\left[{ }^{3} \mathrm{H}\right]$ thymidine was added to each well containing cultures. The mean and standard error of the mean is given.

$\ddagger$ Not statistically significant $P>0.05$.

$\S$ Statistically significant $P<0.005$.

\| Range of observed data. 
TABLE II

Response of Lymphocytes from Old and Young Persons to Allogeneic Lymphocytes*

\begin{tabular}{|c|c|c|}
\hline Responder cell donor & Stimulator cell donor & $\begin{array}{l}\text { Stimulation } \\
\text { index }\end{array}$ \\
\hline & $3,000 \mathrm{rad}$ & \\
\hline \multirow[t]{3}{*}{ Young persons (25) } & All cell combinations tested (74) & $\begin{array}{l}8.1 \pm 0.5 \\
(3.1-23) \ddagger\end{array}$ \\
\hline & Old (42) & $7.9 \pm 0.6$ \\
\hline & Young (32) & $8.4 \pm 0.8$ \\
\hline \multirow[t]{3}{*}{ Old persons (23) } & All cell combinations tested (88) & $\begin{array}{c}5.1 \pm 0.4 \\
(1.5-21) \ddagger\end{array}$ \\
\hline & Old (48) & $5.6 \pm 0.6$ \\
\hline & Young (40) & $4.7 \pm 0.4$ \\
\hline
\end{tabular}

* $2 \times 10^{5}$ lymphocytes and $2 \times 10^{5}$ irradiated allogeneic were cultured in $0.2 \mathrm{ml}$ of medium RPMI 1,640 with $10 \% \mathrm{AB}$ serum for 5 days. $1 \mu \mathrm{Ci}$ of $\left[{ }^{3} \mathrm{H}\right]$-thymidine was added to each well containing cultures $6 \mathrm{~h}$ before the termination of culture. Control cultures consisted of lymphocytes mixed with irradiated autologous lymphocytes. The mean stimulation index and the standard error of the mean is given. The reactivity of responding lymphocytes from old persons is significantly less $(P<0.001)$ than that of lymphocytes from young persons in all cases tested.

$\ddagger$ Range of data observed.

the presence of the plant lectins than do lymphocytes from young persons (Table I).

In the absence of mitogen the difference observed between old and young subjects was not significantly different. However, in the presence of mitogen, thymidine incorporation by lymphocytes from old persons is significantly decreased compared with that by lymphocytes from young persons (Table I). Thus lymphocytes from old subjects do not respond as well to PHA or PWM as do lymphocytes from young persons.

Mixed lymphocyte reactivity of lymphocytes from old and young subjects. Lymphocytes from old persons in mixed lymphocyte culture are stimulated less by allogeneic lymphocytes than are lymphocyte from young persons (Table II). The depressed reactivity was evident when the results of mixed lymphocyte cultures were expressed either as the increment in thymidine incorporated or as the stimulation index which is shown in Table II. As stimulator cells, lymphocytes from old and young subjects functioned equally in mixed lymphocyte culture. Thus, the decreased reactivity observed in mixed lymphocyte cultures from old subjects is due to a decreased capacity of lymphocytes from old persons to react to allogeneic cells. This conclusion is supported by the results of 36 reciprocal cultures included in the data in Table II. When lymphocytes from an old and young person were tested, paired as both responder and stimulator cells, reactivity in $84 \%$ of these reciprocal comparisons was decreased when lymphocytes from the old subject were used as responder cells.
Effect of serum from old and young persons on the mixed lymphocyte reaction. The preceding study of mixed lymphocyte reactivity employed washed lymphocytes cultured in pooled $\mathrm{AB}$ serum and suggested an intrinsic defect in the reactivity of lymphocytes from older subjects. Autologous serum supports lymphocyte transformation in mixed lymphocyte culture better than does pooled $\mathrm{AB}$ serum (Table III). There is, however, no evidence that serum from young persons supports mixed lymphocyte reactivity more effectively

TABLE III

Mixed Lymphocyte Culture in the Presence of Pooled AB Serum and Autologous Serum

\begin{tabular}{cc}
\hline \multirow{2}{*}{$\begin{array}{c}\text { Lymphocyte } \\
\text { donor }\end{array}$} & $\frac{\text { Stimulation autologous serum }}{$\cline { 2 - 2 }} \\
\hline Young (8) & $2.21 \pm 0.36$ \\
& $(1.7-2.9) \ddagger$ \\
Old (7) & $1.90 \pm 0.35$ \\
& $(1.7-2.8) \ddagger$ \\
\hline
\end{tabular}

* Lymphocytes from young and old persons were cultured with irradiated allogeneic lymphocytes in AB plasma and in the serum of the responder lymphocyte donor. The stimulation of thymidine incorporation by mixed cultures in the presence of autologous serum has been divided by that resulting from mixed cultures in the presence of $\mathrm{AB}$ serum. The difference observed is not statistically significant.

$\ddagger$ Range of data observed.

Lymphocyte Function in the Aged 


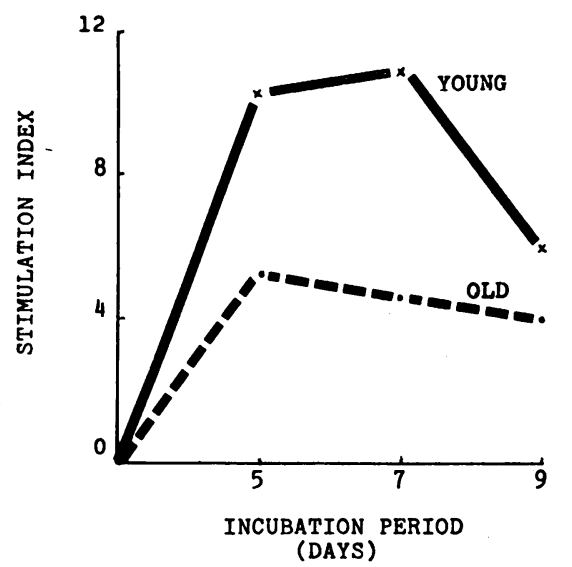

Figure 1 Mixed lymphocyte cultures between three pairs of old and three pairs of young subjects were studied after 5-9 days of culture In each mixed lymphocyte culture $2 \times 10^{5}$ of responding and stimulating lymphocytes were incubated in $0.2 \mathrm{ml}$ of RPMI 1,640 with $10 \%$ AB serum. $6 \mathrm{~h}$ before the termination of cultures $1 \mu \mathrm{Ci}\left[{ }^{3} \mathrm{H}\right]$ thymidine was added to each culture.

than does serum from old subjects. Additional experiments indicated that lymphocytes from old subjects do not react better to allogeneic cells when cultured in serum from young persons and lymphocytes from young persons are not depressed when cultured in serum from old subjects. Thus, no serum factor was found to contribute to the depressed reactivity of lymphocytes from old persons in mixed lymphocyte culture.

Optimal conditions for mixed lymphocyte reactivity. Further experiments were designed to exclude the possibility that the depressed reactivity of lymphocytes from older persons to allogeneic cells results from a difference in optimal culture conditions for mixed lymphocyte reaction. These conditions had been established as optimal using lymphocytes from younger subjects. The mixed lymphocyte reaction between lymphocytes from old and young persons was measured after 5,7 , and 9 days in culture (Fig. 1). The results shown are the mean of an experiment comparing the response of three pairs of old and three pairs of young lymphocyte donors. At each time studied, lymphocytes from young persons responded more actively in mixed lymphocyte culture than lymphocytes from old persons. Other studies showed that maximal thymidine incorporation by responding lymphocytes from either old or young persons required the same number of stimulator cells $\left(2 \times 10^{5}\right)$.

Distribution of thymus-derived and bone marrow-derived lymphocytes in the blood of old and young subjects. Lymphocytes that respond to allogeneic cells in culture are derived from the thymus gland. The depressed reactivity of lymphocytes from old persons in mixed lymphocyte culture may reflect either a reduced number of thymus-derived lymphocytes or a depressed reactivity of a normal number of these cells. To investigate these alternatives, the percentage of thymus-derived lymphocytes in the peripheral blood obtained by the FicollHypaque purification method was determined. Thymusderived lymphocytes were identified by their capacity to form rosettes with sheep erythrocytes (7). Bone marrowderived lymphocytes were identified by their carrying surface membrane immunoglobulin. There was no significant difference in the distribution of thymus-derived or bone marrow-derived lymphocytes in old or young subjects (Table IV). Thus, 79-87\% of blood lymphocytes from both old and young persons could be identi-

TABLE IV

Rosette-Forming Lymphocytes and Immunoglobulin-Bearing Lymphocytes from Blood of Old and Young Persons

\begin{tabular}{|c|c|c|c|c|c|c|}
\hline \multirow[b]{2}{*}{ Experiment } & \multirow[b]{2}{*}{ Blood donor } & \multirow[b]{2}{*}{$\begin{array}{l}\text { Lymphocytes } \\
\text { per ml blood }\end{array}$} & \multirow[b]{2}{*}{$\begin{array}{l}\text { Lymphocytes } \\
\text { recovered } \\
\text { from } 1 \mathrm{ml} \mathrm{blood}\end{array}$} & \multicolumn{3}{|c|}{ Percent of recovered lymphocytes } \\
\hline & & & & $\begin{array}{l}\text { Rosette- } \\
\text { forming } \\
\text { cells }\end{array}$ & $\begin{array}{l}\text { Immuno- } \\
\text { globulin- } \\
\text { bearing } \\
\text { cells }\end{array}$ & $\begin{array}{l}\text { Null } \\
\text { cells }\end{array}$ \\
\hline & & $\times 10^{-5}$ & $\times 10^{-5}$ & $\%$ & $\%$ & $\%$ \\
\hline \multirow[t]{2}{*}{ I } & Young persons $(6)$ & - & - & $79 \pm 1.1$ & $17 \pm 1.1$ & 4.0 \\
\hline & Old persons (6) & - & - & $82 \pm 1.9$ & $15 \pm 1.6$ & 3.0 \\
\hline \multirow[t]{2}{*}{ II } & Young persons (6) & $27.66 \pm 2.38$ & $11.32 \pm 1.25$ & $87 \pm 1.5$ & $12 \pm 1.4$ & 0.7 \\
\hline & Old persons (6) & $24.50 \pm 1.65$ & $10.50 \pm 0.59$ & $86 \pm 1.6$ & $12 \pm 3.1$ & 1.7 \\
\hline
\end{tabular}

Percentage of lymphocytes that formed rosettes with sheep erythrocytes or carried immunoglobulin determinants were assessed in Ficoll-Hypaque purified blood lymphocytes from old and young subjects. The difference in the distribution of lymphocyte markers between old and young persons was not statistically significant. The number of lymphocytes in the blood of old and young persons was not significantly different and their recovery was comparable. 
fied as thymus derived, $12-17 \%$ as bone marrow derived, and $0.7-4.0 \%$ of the lymphocytes reacted with neither anti-immunoglobulin nor sheep erythrocytes.

\section{DISCUSSION}

This study demonstrates that lymphocytes from old persons have a decreased mitogenic response to plant mitogens and allogeneic lymphocytes when compared with lymphocytes from young persons. This functional difference in lymphocytes from old subjects cannot be attributed to a difference in conditions required for optimal lymphocyte transformation in vitro such as the source of serum, duration of culture, or number of stimulating cells. The absolute number of lymphocytes (8) and the percentage of thymus-derived lymphocytes in the blood of old and young subjects is identical. The altered reactivity observed probably results from a deficiency or dysfunction of that subset of thymus-derived lymphocytes that respond to foreign histocompatibility antigens. As the number of thymus-derived lymphocytes is maintained in aged subjects it is more likely that a cofactor necessary for the expression of cellular immunity is deficient. Recently, the concentration of thymosin in the blood has been found to decline with age (9). A low level of thymosin may be related to the impaired reactivity of lymphocytes from old subjects.

Impaired immunologic reactivity has been recognized in aged experimental animals and man. Both cellular and humoral immunity are altered in the aged. Animal studies by Makinodan Perkins, and Chen (10) have revealed that 100 -wk old mice retain only $10 \%$ of their humoral response to sheep erythrocytes found in 20-wk old animals. Simonsen (11) showed that lymphocytes from old animals did not induce graft-vs.-host disease and recently Konen, Smith, and Walford (12) reported that lymphocytes from old mice have a depressed reactivity in mixed lymphocyte culture.

Studies in man have also revealed that the aged are immunologically compromised. Waldorf, Willkens, and Decker (13) found that significantly fewer old subjects can be sensitized to dinitrochlorobenzene and Anderson (14) showed that aged persons do not express the lymphocyte transfer reaction normally. The latter observation is particularly relevant to the present study as the lymphocyte transfer reaction is a mixed lymphocyte reaction carried out in vivo. The response of lymphocytes from persons of different ages to PHA in vitro has been studied by Pisciotta, Westring, De Prey, and Walsh. Lymphocyte transformation induced by PHA declined progressively with the age of the lymphocyte donor. This defect was not attributable to an effect of serum from old persons and has been confirmed in this study.
The factors responsible for the immune defect seen in the aged has been most extensively studied by Price and Makinodan (16). Using limiting dilution analysis, these investigators found that the number of splenic immunocompetent units in aged mice was $\frac{1}{10}$ that found in young animals. Not only was a deficiency of lymphoid elements found but an impairment in "antigen processing" was suggested by the need to raise the immunizing dose of antigen 10-fold to maximally stimulate old mice. In further studies (17) a defect in addition to that found in the splenic lymphoid population was demonstrated by the fact that splenic lymphocytes from young animals were less active when transferred into old as compared with young irradiated syngeneic recipients.

The significance of the waning of immunologic vigor is debated. Burnet (18) and Walford (19) have suggested that age-related immunologic incompetence may be causally related to the aging process itself and the increasing incidence of cancer and so-called, "autoimmune" phenomena with age. These suggestions have been supported by experimental studies. Fabris, Pierpaoli, and Sorkin (20) have shown that the transfer of lymph node lymphocytes from normal Snell-Bagg mice prolongs the life of dwarf Snell-Bagg mice which normally die prematurely. Stjernsward (21) has shown that the resistance of mice to transplanted tumors at various ages is closely correlated with their capacity to respond to sheep erythrocytes. Teller, Stohr, Curlett, Kubisek, and Curtis (22) showed that the decline of immune competence in aging Swiss mice as measured by their capacity to reject skin and tumor grafts was directly correlated with an increasing incidence of spontaneous tumors. The results of our study in man supports the immune surveillance hypothesis. In fact, the tumor-free, aged subjects we studied may have possessed significantly better immune reactivity than patients who had died, developed cancer, or developed autoimmune diseases. Only a prospective study will document whether a depression of immunologic reactivity is a significant risk factor in premature death, or the occurrence of cancer or autoimmune diseases in man.

\section{ACKNOWLEDGMENTS}

This work was supported in part by a grant from the New York Cancer Research Institute and grants CA 13339 and AM 11796 from the National Institutes of Health.

\section{REFERENCES}

1. Dorn, H. F., and S. J. Cutler. 1959. Morbidity from cancer in the United States. Public Health Monogr. No. 56.

2. Boyum, A. 1968. Separation of leukocytes frem blood and bone marrow. Scand. J. Clin. Lab. Invest. 21 (Suppl.) : 97.

3. Hartzman, R. J., M. Segall, M. L. Bach, and F. H. 
Bach. 1971. Histocompatibility matching. VI. Miniaturization of the mixed leukocyte culture test: a preliminary report. Transplantation. 11: 268.

4. Hütteroth, T. H., H. Cleve, and S. D. Litwin. 1973. Modulation of membrane associated immunoglobulins of cultured human lymphoid cells by specific antibody. J. Immunol. 110: 1325 .

5. Goldstein, G., I. S. Slizys, and M. W. Chase. 1961. Studies on fluorescent antibody staining. I. Nonspecific fluorescence with fluorescein-coupled sheep anti-rabbit globulins. J. Exp. Med. 114: 89.

6. Weiner, M. S., C. Bianco, and V. Nussenzweig. 1973. Neuraminidase enhancement of the binding of sheep erythrocytes to human $\mathrm{T}$ lymphocytes. Blood. In press.

7. Jondal, M., G. Holm, and H. Wigzell. 1972. Surface markers on human $\mathrm{T}$ and $\mathrm{B}$ lymphocytes. I. A large population of lymphocytes forming non-immune rosettes with sheep red blood cells. J. Exp. Med. 136: 207.

8. Shapleigh, J. B., S. Mayes, and C. V. Moore. 1952. Hematologic values in the aged. J. Gerontol. 7: 207.

9. Schulof, R. S., J. A. Hooper, A. White, and A. L. Goldstein. 1973. Development of radioimmunoassays for human and bone thymosin. Fed. Proc. 32: 962. (Abstr.).

10. Makinodan, T., E. H. Perkins, and M. G. Chen. 1971. Immunologic activity of the aged. Adv. Gerontol. Res. 3: 171 .

11. Simonsen, M. 1960. Cellular aspects of immunity. Ciba Foundation Symposium. C. E. W. Wolstenholme and M. O'Connor, editors. Little Brown \& Co., Boston.

12. Konen, T. G., G. S. Smith, and R. L. Walford. 1973.
Decline in mixed lymphocyte reactivity of spleen cells from aged mice of a long-lived strain. J. Immunol. 110: 1216 .

13. Waldorf, D. S., R. F. Willkens, and J. L. Decker. 1968. Impaired delayed hypersensitivity in an aging population. J. Am. Med. Assoc. 203: 111 .

14. Anderson, E. 1972. The influence of age on transplantation immunity. Scand. J. Hematol. 9: 621.

15. Pisciotta, A. V., D. W. Westring, C. DePrey, and B. Walsh. 1967. Mitogenic effect of phytohemagglutinin at different ages. Nature (Lond.). 215: 193.

16. Price, G. B., and T. Makinodan. 1972. Immunologic deficiencies in senescence. I. Characterization of intrinsic deficiencies. J. Immunol. 108: 403.

17. Price, G. B., and T. Makinodan. 1972. Immunologic deficiencies in senescence. II. Characterization of extrinsic deficiencies. J. Immunol. 108: 413.

18. Burnet, F. M. 1970. Immunological Surveillance. Pergamon Press Ltd., Oxford.

19. Walford, R. L. 1969. The immunologic theory of ageing Munksgaard, A/S, Copenhagen.

20. Fabris, N., W. Pierpaoli, and E. Sorkin. 1972. Lymphocytes, hormones and ageing. Nature (Lond.). 240:557.

21. Stjernsward, J. 1966. Age-dependent tumor-hosts barrier and effect of carcinogen-induced immunodepression on rejection of isografted methylcholanthrene-induced sarcoma cells. J. Natl. Cancer Inst. 37: 505.

22. Teller, M. N., G. Stohr, W. Curlett, M. L. Kubisek, and D. Curtis. 1964. Ageing and carcinogenesis. I. Immunity to tumor and skin grafts. J. Natl. Cancer Inst. 33: 649 . 